\title{
Before "Surfurbia": The Development of the South Bay Beach Cities through the 1930s
}

\author{
Ronald A. DAvidson \\ California State University, Northridge
}

\begin{abstract}
Few landscapes have been more trivialized for global consumption than the southern California beach. "Baywatch," "Beach Blanket Bingo," and Rayner Banham's coinage of the term "Surfurbia" are among the myriad examples of culture products that depict the shore as a homogeneous fun space lacking historical and cultural complexity. However, the South Bay communities from El Segundo to Torrance (essentially the cities that Banham called "Surfurbia") have long histories, examination of which reveals the richness and complexity of their geographies. The different cities emerged under the influence of a variety of developmental forces so that, despite the monolithic image of "Surfurbia," the rise of the South Bay is in fact many separate, incompatible stories.
\end{abstract}

\section{Introduction}

In LOS ANGELES: THE ARCHITECTURE OF FOUR ECOLOGIES, British landscape architect Reyner Banham (2001) christened the concatenation of South Bay cities stretching from El Segundo to Redondo Beach "Surfurbia," a term that evoked "the surfside way of Angeleno life" (p. 47) (Figure 1). Banham was a visitor who took in Los Angeles through "the rearview mirror" (p. 3), that is, on the move, the way he thought Los Angeles was meant to be seen. Glimpsed this way, the "surfside" culture of Los Angeles seemed a blissful refuge from the complexity and cupidity of capitalist society. "Give me a beach, something to eat, and a couple of broads, and I can get along without material things," a Santa Monica bus driver told Banham (p. 38). The author concluded that "The culture of the beach is in many ways a symbolic rejection of the values of the consumer society, a 


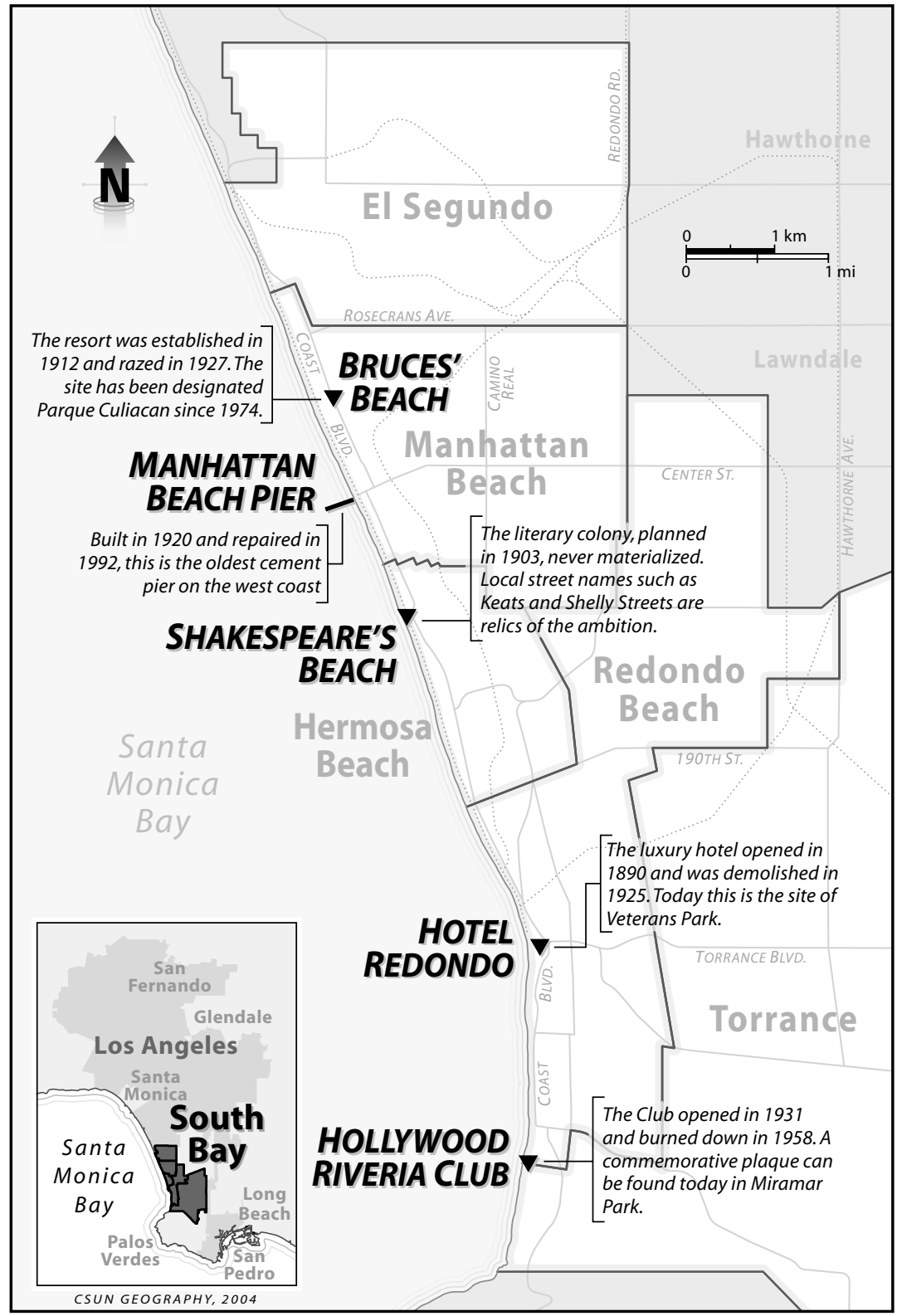

Figure 1. The South Bay, circa 1930. The region was already a diverse collection of emergent and relict cultural landscapes. 
place where a man needs to own only what he stands up in-usually a pair of frayed shorts and sun-glasses" (pp. 38-9).

Banham's image of the Los Angeles shore as a bohemian paradise is widely shared. It has been promulgated for decades by a diverse array of popular-culture products including novels, movies, and television shows, which influence the perceptions of audiences around the world. It also appears, as evidenced by Banham's book, in more serious academic writing. But the image is highly superficial. It presents the coast as a homogeneous fun zone lacking culture and history. Indeed, it could be argued that few landscapes have been more thoroughly trivialized for global consumption than the Southland's coast.

In this paper, I seek to evoke some of the cultural-geographic texture of the South Bay that the image of "Surfurbia" currently masks. To achieve this goal, I describe the historical development of the five major South Bay communities-El Segundo, Hermosa Beach, Manhattan Beach, Redondo Beach, and Torrance-through the 1930s. My goal is not to provide a comprehensive study but a cursory overview and invitation to deeper exploration by the scholar or general reader. While the pre-history and European history of the area are complex and interesting, I will focus on the American period, the period trivialized by the "Surfurbia" image. I will show that the South Bay in this period is not a homogeneous space, but a diverse collection of places that tell many geographic stories. These include stories about rapid economic growth but also setbacks and periods of stagnation; about entrepreneurs with lofty and progressive cultural ambitions and others who simply wanted money; about the role of big corporations in transforming the region and the impact of the workers who resisted them.

Two inadequacies of the stereotype image of the coast are so great that they should be mentioned at the outset, however. The first is the way in which the image ignores the distinction between what Banham called the "surfurbs" and Los Angeles city proper. The South Bay communities of El Segundo, Manhattan Beach, Hermosa Beach, Redondo Beach, and Torrance are distinct, incorporated cities with their own identities and historical experiences. In large and small ways, the histories of their coastal landscapes 
reflect these differences. Also inadequate is the image of the coast as the setting of a simplistic, "beach-bum"-type lifestyle outside of a commercialized, materialistic culture. In fact the coast has historically been-and continues to be-a prime basis for generating real estate wealth in these communities. To view the coast in isolation from the development and entrepreneurship that it has made possible is to strip it of much of its significance. At the same time, it could be argued, the lifestyle on the beach has had an impact on the culture of Los Angeles, allowing urbanites to de-stress and perhaps encouraging a more easygoing, less materialistic attitude in some of them (see, for example, Krier 1979 and Edgerton 1979).

\section{The 1800s}

Until the late $19^{\text {th }}$ century, much of the South Bay was used for cattle and sheep grazing on large rancho tracts and, after the drought of the mid-1870s that decimated livestock populations, dry farming of barley and other crops. Anglo-American industrial activity was present as early as 1855, however, when entrepreneurs Henry Allanson and William Johnson purchased more than 200 acres of land from the Dominguez Rancho in what is now Redondo Beach (Johnson 1965). They built the Pacific Salt Works next to a cluster of salt ponds that originally were used by the Native Americans to harvest and sell salt to tribes based in the San Gabriel Mountains. Fuel wood to heat the salt works boilers was supplied by willows growing on the north slope of the Palos Verdes hills (Grenier and Gillingham 1987). When land prices rose 2 years later, the firm of Vail and Freeman established the townsite of Redondo Beach (which would be incorporated in 1892) (Myers and Swett 1976). The town's name, Spanish for "round," was inspired either by the curving shoreline, the curving streets planned around an oval in the center of town, or from the name of the Rancho of which it had been part (the El Sausal Redondo rancho, meaning "The round clump of willows") (Myers and Swett 1976, p. 50).

Development was further stimulated in the area by developers Capt. J. C. Ainsworth and Capt. R. R. Thompson, who endeavored to lure tourists and real-estate investors. After working out a deal with the Dominguez sisters, heirs to the original rancho, they re- 
laid the city in blocks and named the north-south streets after Spanish women and the east-west streets after precious stones. The population and economy would grow only modestly, however, until after the turn of the century, when Henry Huntington turned his attention to developing Redondo Beach (Johnson 1965). In the meantime, however, infrastructure construction spurred some growth and could have-but ultimately did not - trigger massive industrial development in the form of port facilities. This began in 1889 when the Santa Fe Railroad completed laying track from Los Angeles to Redondo Beach. The following year, a deepwater canyon was discovered offshore at Redondo, and the Santa Fe found itself in position to transport cargo from a newly constructed wharf at the site to downtown Los Angeles (Pipkin 1985). In 1890, the railroad added a passenger line to Redondo and built a magnificent, English-themed hotel at the present-day site of Veteran's Park. The 225-room Redondo Hotel, whose sister is the Hotel Coronado, had lavish amenities for its time, such as a bathroom on every floor, steam heat, landscaped gardens, a ballroom, an 18-hole golf course, and tennis courts on the beach (Johnson 1965, p. 49). But the Santa Fe's larger ambition was to use the natural harbor at Redondo to build the region's main seaport. The Southern Pacific Railroad, on the other hand, hoped Santa Monica would be chosen for the port, while a third company, the Terminal Railroad, pushed for San Pedro. The Santa Fe argued that Redondo was closer to San Francisco than San Pedro and, unlike Santa Monica, it had a natural deep-water harbor. However, it did not have a protective breakwater. In 1897, a five-man board of engineers resolved the "harbor fight" (Deverell 1991) in the Terminal Railroad's favor, recommending that San Pedro become the main port for the region (Port of Los Angeles 2003). After this decision, industrial waterfront activity declined in Redondo, and tourism and recreation once again became the town's main activities (Pipkin 1985).

\section{1-1910}

In 1903, the Pacific Railway Company stimulated South Bay development by completing a trolley line from Los Angeles to Santa Monica and thence down the coast to Redondo Beach. This made 
casual day-tripping to the beach much easier and also increased the popularity of resort facilities from Redondo to Manhattan Beach. Prior to the railroad era, people had traveled to the South Bay beaches from Los Angeles and Inglewood by horse and buggy. They had had to tie their horses to trees on the inland sides of the dunes and walk to the shore because it was difficult to get buggy wheels through beach sand (Dennis 1987). The area's beach cottages initially were set back 2 or 3 blocks from the berm to avoid the shifting sand dunes and frequent sandstorms closer to shore (McCallister 1978). A women's organization, the Neptune Society, planted ice plant to anchor the dunes (MB 2003). Meanwhile, in 1902, two developers of adjacent landholdings flipped a coin to decide the name of their town. George Peck had been calling his northern section "Shore Acres," after the local Santa Fe station, and John Merrill had named his southern part "Manhattan," after his home town. Merrill won, and the town became Manhattan Beach at the behest of the postmaster, who sought to avoid confusion with 14 other Manhattans in the country (MB 2003).

As mentioned earlier, Redondo Beach grew but slowly in the years after Ainsworth and Thompson laid out the town. Henry Huntington's brother quipped that the very name Redondo made a capitalist "shy like a horse at an automobile" (quoted in Whitcomb 2000, p. 39). Nonetheless, in 1905, Henry Huntington announced his intention to purchase the Redondo Improvement Company, which owned most of Redondo Beach (Friedericks 1989). Huntington had already gained control of the Redondo Railway, which operated two lines from Los Angeles (Fredericks 1989). "The magic name of Huntington," as the Los Angeles Times put it, emboldened speculators and triggered a 2-week real-estate frenzy. Agents set up more than 100 real-estate offices, some in tents, on Front Street. Huntington placed ads in the Los Angeles Times promising "Free Excursions Every Twenty Minutes!" to Redondo where the "Dirt is Flying! Spikes Are Being Driven!" (advertisements quoted in Whitcomb 2000, p. 39). As a result of the boom, Huntington sold about three million dollars worth of Redondo Beach property (Whitcomb 2000). 
Although some investors lost money when property values fell after the boom, Huntington invested heavily in Redondo Beach and did encourage long-term development. In 1907 he constructed a 3story pavilion with a ballroom, restaurant, and theater at Coral Way and Midway (Friedericks 1989). In 1909. he opened the Plunge, advertised as the largest indoor salt water plunge in the world. It had three heated pools, steam and Turkish baths, and more than 1,000 dressing rooms. The complex could hold 2,000 bathers at a time. For 30 years, the Plunge was a major West Coast attraction (Shanahan 1982).

To lure the public to Redondo, Huntington hired George Freeth, now considered the father of modern-day surfing, to exhibit the sport to crowds gathered on the shore. Huntington had learned of Freeth from Jack London, who had written an account of Freeth and his littoral avocation in "A Royal Sport," an essay first published in $A$ Woman's Home Companion in 1907 (Whitcomb 2000). London had met Freeth after sailing his Snark to Waikiki Beach earlier that year. Entranced by Freeth's ability to "walk on water," London asked for lessons. He wrote in his essay: "Shaking the water from my eyes as I emerged from one wave and peered ahead to see what the next one looked like, I saw [Freeth] tearing in on the back of it, standing upright on his board, carelessly poised, a young god bronzed with sunburn" (Bandanna College).

Soon after the essay was published, Huntington's agents arrived in Hawaii to offer Freeth a job. From then until his death from influenza a dozen years later, Freeth would demonstrate surfing on a heavy wooden board at Redondo Beach. He also demonstrated diving techniques in the plunge. Freeth not only introduced surfing to southern California, but became the first professional lifeguard and the inventor of a "rescue can," a large bucket on a cable that could be thrown to drowning swimmers (Whitcomb 2000).

Redondo Beach grew rapidly around Huntington's splashy attractions, more than quintupling in population from 855 in 1900 to 4,900 in 1920 (Friedericks 1989). Meanwhile, a more culturally lofty beach community was being planned nearby at the Hermosa BeachManhattan Beach border. In 1903, Moses Sherman and Eli P. Clark-the developers who built the Los Angeles Pacific Railway 
down the coast-attempted to establish a literary colony called Shakespeare's Beach at the site (Roebuck 1987). The bid was unsuccessful, however, so the developers built and sold beach cottages instead (Roebuck 1987). Evidence of the entrepreneur's abandoned dream can be found today in the street names of the area, which include Longfellow Avenue and Keats, Shelly, and Tennyson Streets.

\section{1-1920}

Large-scale industries came to the South Bay coast in the 1910s, and with them came El Segundo and Torrance. The first of these industrial towns developed with little opposition, but the second struggled against labor opposition and did not develop as planned. El Segundo was a product of the Standard Oil Company, which constructed a refinery in 1911 at the site for oil pumped from the Fullerton and Torrance oil fields. Standard Oil chose the refinery site because the land was cheap and undeveloped, was located near water for cooling, and included a large dune tract. Storage tanks were located on the dune ridge, so that oil could flow by gravity to tankers offshore. Pocket-depressions in the dunes would contain leaks and minimize the danger of explosions. The sparseness of the dune vegetation minimized potential fire hazard (Gerlach 1940). The El Segundo Land Improvement Co. acquired the townsite, for housing the refinery's workers, to the north of the refinery. The name El Segundo ("the Second One") refers to the fact that it was the second oil refinery in California (Pipkin 1985). A harbor was constructed for tankers to load the oil, but it was destroyed by an underwater earthquake in 1914. The company subsequently built a pipeline to allow tankers to load up and take the oil to other ports in the US, Asia, and Australia (Gerlach 1940).

The creation of the El Segundo refinery spurred the growth of Hermosa Beach and Manhattan Beach. Until 1910, these areas had existed as resorts with beach cottages and had several hundred permanent residents. Now they became "black gold suburbs," residential suburbs for refinery workers (Viehe 1991). In the teens and 20s, black gold suburbs were the fastest-growing areas in southern California. For example, from 1910 to 1920, Hermosa Beach grew at a 243 percent rate (Viehe 1991). The growth of these suburbs indi- 
cated the preference of oil industry workers to live near their jobs, but in residential rather than industrial suburbs. Other black gold suburbs included the San Pedro-Long Beach and Vernon-Huntington Park clusters (Viehe 1991).

Torrance was founded a year after El Segundo, in 1912, but its development would not go as smoothly. The city's namesake, Jared S. Torrance, was vice president of Union Oil and its subsidiary Union Tool Companies (Phelps 1995). In 1912, he persuaded Union Tool to purchase land from the Dominguez Estate Company. The land, a windy tract of sand and agricultural fields, was inexpensive at a time when Los Angeles real estate prices were rising sharply (Shanahan and Elliot 1984). It was also removed from the utilitarian, gritty industrial corridor along the Los Angeles River and offered room for residential and industrial development (Phelps 1995). At this time, the region was afflicted with widespread labor unrest that occasionally erupted into violence. In 1910, the main building of the assertively open-shop Los Angeles Times had been bombed by union activists. Other bombings and manifestations of labor unrest flared in southern California. In this context, Torrance sought to create an industrial town based on the garden city concept that would defuse tensions by virtue of being a pleasant place to live and work (Shanahan and Elliot 1984, Phelps 1995). The firm of John C. and Frederick Law Olmsted, Jr. was hired, for \$5,000 (and subsequent consulting fees), to design the western United State's first "model industrial city" with a planned population of 15,000 inhabitants (Shanahan and Elliot 1984). The Olmsted plan borrowed elements from the City Beautiful, City Practical, and National Playground movements in an attempt to combat the ugliness of industrial cities by creating an urban landscape of utility, efficiency, and beauty (Phelps 1995). The Pacific Electric station formed the hub of the city, with industrial properties arranged in linear patterns alongside the tracks. Housing was located upwind of the factories. A shopping center and residential park were located to maximize interaction among different social classes, which the Olmsteds believed would instill better values in the lower ones. A hundred thousand trees were planted to create a garden-city environment (Phelps 1995). 
Not as many workers bought lots as the developers hoped, however. Shortly after the housing sites went to market, the economy soured. Moreover, much of the employment initially offered in Torrance was too sporadic to inspire workers to make long-term investments in houses. The town also met fierce resistance from labor leaders who saw the project as an attempt by capitalists to pacify and control non-union workers. As a consequence of these factors, most Union Tool employees chose to live outside the town and commute to work on the Pacific Electric cars. In 1922, the city had only 2,500 residents, far fewer than planned. Only after Torrance shed its model industrial city image did its population significantly grow (Phelps 1995).

In 1912, the same year Torrance was founded as-at least according to labor leaders-an oppressive enclave, Manhattan Beach created a truly progressive enclave, a resort for African Americans. But even as progressive forces would help to thwart the Torrance development, racist oppressors would close down Manhattan Beach's resort. When Manhattan Beach was incorporated in 1912, no places on the southern California coast welcomed minorities. Racially restrictive covenants prevented blacks from moving into white shorefront neighborhoods. Flouting this tradition, developer George Peck established a 2-block area fronting the beach between Twenty-Sixth and Twenty-Seventh Streets for minority residents. Mrs. Willie A. Bruce was the first African American to buy lots at the site (McCallister 1978). She and her husband, Charles, built a bathhouse and lodge for African Americans at what became known as Bruces' Beach. Accomodations included a 2-story structure with a dance floor upstairs and a café below. Peck also helped the Bruces build a fishing pier (McCallister 1978).

As the value of coastal real estate increased, however, white hostility toward the African Americans of Bruces' Beach increased. Racial intolerance expressed itself in various forms, reportedly including cross-burning by members of the Ku Klux Klan (Drake 2003). Long-time (white) resident Wilmer Drake recalls that African Americans risked being arrested if they went to public places in the city after dark (Drake 2003). 
In 1924, city officials condemned the neighborhood, ostensibly to build a park on the site. When the families refused to sell their properties to the city at below market value, the city seized the land under eminent domain. The Bruces and three other African-American families sued the city. In a gesture of at least partial fairness, the judge insisted that the plaintiffs be allowed to live elsewhere in the city, if not adjacent to the beach. In 1927, Bruces' Beach Resort was razed, along with other cottages on the site. The Bruces received $\$ 14,500$ and left the city. In 1924, a blacks-only section of Santa Monica Beach, called the Inkwell, opened near the foot of Pico Boulevard (Rasmussen 2002).

Manhattan Beach did not build a park on the site of Bruces' Beach until the 1950s. Since 1974, it has been designated Parque Culiacan, signifying the link to Manhattan Beach's sister city in Sinaloa, Mexico (Pena 2004, Rasmussen 2002).

\section{1-1930}

In 1920, while the Bruces and their neighbors were being forced out of Manhattan Beach, the growing town sought to lure additional (white) settlers and investors by constructing a 928-foot-long cement pier with an unusual, rounded front end (MB 2003). This was not the first pier built in the area, but it overshadowed earlier, smaller piers that had been damaged or removed. Remnants of one of these, the "Old Iron Pier," completed in 1901, for decades would remain underwater hazards to those who dove from the Manhattan Beach Pier (McCallister 1978). In 1991, after decades of wear and tear, the city decided to restore the 1920 pier to its original form. Restoration was complete in 1992, and in 1995 the pier-the oldest standing cement pier on the West Coast—was declared a state historic landmark (MB 2003).

As Manhattan Beach grew in the 1920s, it confronted a longstanding obstacle to its development, shifting sand dunes. Sand frustrated development by inhibiting the construction of buildings on level land and by constantly blowing across boardwalks, roads, and railroad tracks. Railroad companies hired teams of Mexican workers to clear the sand from the tracks, but trains were delayed for hours at a time (Dennis 1987). To level the landscape for the con- 
struction of buildings, a more effective solution was needed. The Kuhn Brothers Construction Company solved the problem when they found a buyer for Manhattan Beach sand in Hawaii. For nearly 10 years, the sand was taken by Santa Fe railroad cars to San Pedro harbor and shipped to Waikiki Beach, where it was spread over the pebbly shore (MB 2003). A letter writer noted in the Los Angeles Times: "Many a honeymooner has since returned from Hawaii with a little vial of Waikiki Beach sand - that actually came from the South Bay" (McCafferty 1992). Manhattan Beach sand was also used as ballast in Santa Fe and Southern Pacific railroad cars, in the flooring of Los Angeles Memorial Stadium, and elsewhere in the state and in Arizona (Dalton 1976; Moon 1952). Not all of the sand dunes were removed, however. The dune system stretching from El Segundo to Manhattan Beach provided an ideal location for shooting desert scenes in early Hollywood films such as The Sheik (Pipkin 1985).

Also in the mid 1920s, Oregon-born entrepreneur Clifford Reid arrived in southern California with several big plans. One of them was to develop a square mile of land in present-day Torrance into California's equivalent of the French Riviera (Shanahan and Elliot 1984). Reid planned the "Hollywood Riviera," linked by a local parkway to the Culver City and Gower Street studios, to be a coastal playground for the region's movie elite. While initial sales were strong, few Hollywood people were among buyers. The onset of the Depression slowed sales considerably. In 1931, the Hollywood Riviera Club opened above the beach west of Paseo de la Playa at the foot of Calle Miramar. The boundary separating Torrance and Redondo Beach ran through the club, and because the rules about drinking alcohol differed in the two cities, people had to change their positions to continue drinking legally at times (Shanahan and Elliot 1984). The club burned down in 1958, and a plaque dedicated to preserving its memory can be found today by the steps in Miramar Park (Payne 2003).

Illegal economic activities also took place in the South Bay into the early 1930s and after. During Prohibition, alcohol runners would sail their cargo past the shore. Once, recalls Manhattan Beach resident Wilmer Drake, a police boat chased liquor smugglers off the beach. The smugglers dumped their cargo overboard and cases of 
Canadian Club whiskey washed ashore. The precedent for smuggling in Manhattan Beach was set half a century earlier: In the 1870s, Manhattan Beach resident Col. Thomas Duncan, from Virginia, built a house at what is now First Street and Sepulveda Boulevard. Duncan reportedly signaled to smugglers from a lookout tower on his roof, facilitating an underground trade in opium and other commodities brought from Mexico, England, and the Spanish Philippines (Shanahan 1982).

\section{Conclusion}

The South Bay cities developed rapidly, starting around the turn of the $20^{\text {th }}$ century, but with significant variation in the speed and the bases of growth. Tourism and resort activities were sources of steady growth, although two culturally lofty resort projects-the literary colony at Shakespeare's Beach and the African-American resort at Bruce's Beach-ultimately failed. While the Santa Fe's luxury hotel and Huntington's Plunge were immediate successes, the Hollywood Riveria in Torrance also suffered setbacks. This suggests an uneven pattern of resort development along the South Bay coast, something not implied by the trouble-free, glamorous image the beach zone enjoys today. Large-scale industrial activity began after a period of resort growth and contributed to the area's development after 1910, although in the case of the "model industrial city" of Torrance this growth was sluggish for a decade. The rise of the South Bay, in short, entails not one geographic story but many. None of these stories are reflected in the static and simplistic image of "Surfurbia" that exists in popular culture and even-as in the case of Banham's book-in some more serious accounts of the area. Interested readers are encouraged to visit the historical societies of the cities to learn more about them.

\section{Literature Cited}

Bandanna College. 2003. Bandanna College of Humanities. http:/ / www.bandannacollege.com/bandannabooks/surftext.html. Accessed December 5.

Banham, Reyner. 2001. Los Angeles: The architecture of four ecologies. Berkeley: University of California Press. 
Dalton, Rex. 1976. “Manhattan: isle's sandman." The Daily Breeze. October 13, B1.

Dennis, Jan. 1987. A walk beside the sea. Manhattan Beach: Jansatan Studio. Deverell, William. 1991. "The Los Angeles 'free harbor fight'." California History. 70(1):12-29.

Drake, Wilmer. 2003. Docent at Manhattan Beach Historical Society. Interviewed November.

Edgerton, Robert B. 1979. Alone together: Social order on an urban beach. Berkeley, CA: University of California Press.

Friedericks, William. 1989. "Henry E. Huntington and real estate development in Southern California, 1898-1917." Southern California Quarterly. Winter:327-40.

Gerlach, Arch C. 1940. "Growth of El Segundo, California." Economic Geography. 16(2):225-230.

Grenier, Judson A. and Robert C. Gillingham.1987. Califoria legacy: The James Alexander Watson-Maria Dolores Dominguez de Watson family, 1820-1980. Los Angeles: Watson Land Company.

Johnson, Ken. 1965. Fun, frustration and fulfillment: An historical study of the City of Redondo Beach. [s.i.]:[s.n.].

Krier, Beth Ann. 1979. "Safe Harbor: The Sea as Therapy." Los Angeles Times. September 16, viii:1.

MB. 2003. Manhattan Beach Historical Society. http:/ / www.geocities. com/history90266/. Accessed November.

McCafferty, John. 1992. Letter to the editor. Los Angeles Times. Jan. 5, M4.

McCallister, Linda Chilton. 1978. The waterfront of Manhattan Beach: An historical sketch. Manhattan Beach Historical Series, publication no. 6. Manhattan Beach, CA: Manhattan Beach Historical Society.

Moon, John. 1952. "Story of Manhattan written in sands; but they moved 'em to allow growth," Daily Breeze. Jan. 1.

Myers, William A. and Ira L. Swett. 1976. Trolleys to the surf: The story of the Los Angeles Pacific Railway. Glendale: Interurbans.

Payne, Janet. 2003. Vice President of Torrance Historical Society. Interviewed December.

Pena, Rebeca. 2004. Administrator, City of Manhattan Beach. Interviewed April.

Phelps, Robert. 1995. "The search for a modern industrial city: Urban planning, the open shop, and the founding of Torrance, California." Pacific Historical Review. 64:503-535.

Pipkin, Bernard. 1985. "Santa Monica to Dana Point." In Gary Griggs and Lauret Savoy, eds., Living with the California coast, pp. 307-329.

Durham, North Carolina: Duke University Press. 
Port of Los Angeles. 2003. Port of Los Angeles Virtual History Tour. www.Laporthistory.org. Accessed December 5.

Rasmussen, Cecilia. 2002. "Resort was an oasis for blacks until racism drove them out." Los Angeles Times. July 21, B4.

Roebuck, Karen.1987. "Shakespeare society would put bard back on the beach Manhattan." Los Angeles Times. April 26, Southbay edition, p.1.

Shanahan, Dennis. 1982. Old Redondo: A pictorial hsitory of Redondo Beach. Redondo Beach: Legends Press.

Shanahan, Dennis F. and Charles Elliot, Jr. 1984. Historic Torrance: A pictorial history of Torrance, California. Redondo Beach: Legends Press.

Viehe, Fred W. 1991. "The social-spatial distribution in the black gold suburbs of Los Angeles, 1900-1930." Southern California Quarterly. 73(1):33-54.

Whitcomb, Ian. 2000. "The beach boy." American Heritage. 51(41):34-45. 